\title{
Funkcjonowanie leśnych przedszkoli - Waldkindergaerten - w Niemczech a obraz dzieciństwa we współczesnym świecie
}

\section{KEY WORDS}

forest kindergarten in Germany, modern concepts of childhood, direct contact with nature

\begin{abstract}
Pieprzyk Maria, Funkcjonowanie leśnych przedszkoli - Waldkindergaerten - w Niemczech a obraz dzieciństwa we współczesnym świecie [Forest Kindergarten - Waldkindergaerten - in Germany and the Modern Concepts of Childhood]. Kultura - Społeczeństwo - Edukacja nr 1(7), 2015, Poznań 2015, pp. 121-134, Adam Mickiewicz University Press. ISBN 978-83-232-2944-5. ISSN 2300-0422

The paper deals with the issue of forest kindergartens as presented in the German concept of Waldkindergarten. This concept makes a new way of thinking about child pedagogy. These kindergartens are designed to support the child in its creative process along the fact to encourage the child to further explore the surrounding nature. These specific institutions might be regarded as an answer to the challenges of modern childhood, in which the child is exposed to a toxic environment. This very toxicity could be regarded also metaphorically as a pollution of the mind through media and technology.
\end{abstract}

\section{Wprowadzenie}

Leśne przedszkola są odpowiedzią na wyzwania i problemy współczesnego dzieciństwa, na które chociażby negatywnie wpływa dynamiczny rozwój cywilizacji. Der Waldkindergaerten (po przetłumaczeniu z języka niemieckiego oznacza to leśne przedszkola) w Niemczech są nową alternatywą i perspektywą w przedszkolnej pedagogice. Decydujące dla zakładania organizacji tego rodzaju były społeczne przemiany, które z biegiem czasu prowadziły do zakłócenia możliwości doświadczalnych u dzieci i ich prawidłowego rozwoju psychofizycznego. Leśne przedszkola dają dzieciom szansę na dzieciństwo, w którym jest czas na swobodną zabawę, bliski kontakt $\mathrm{z}$ przyrodą, polisensoryczne doświadczenia, 
bezpośrednie przeżywanie rytmu pór roku, poznanie siebie i swoich zainteresowań.

Bogactwo kształtów, barw, różnorodność zjawisk w świecie przyrody rozbudza ciekawość i zainteresowania dzieci. Otaczająca nas natura nasuwa wiele pytań, na które najmłodsi chętnie szukają odpowiedzi. Toteż można i trzeba wręcz wykorzystywać kontakt dziecka z przyrodą dla jego ogólnego rozwoju (Daszewska, 1948: 7).

Dzieci na całym świecie tracą kontakt z przyrodą - lepiej rozpoznają zwierzęta z egzotycznych krajów i z bajek, niż te żyjące w ich najbliższym sąsiedztwie. Naukowcy biją na alarm, bo szkodzi to i dzieciom, i ochronie przyrody. (Mikołuszko, 2012: 62)

Życie $\mathrm{z}$ dala od natury niesie ze sobą wiele negatywnych konsekwencji dla prawidłowego rozwoju dziecka.

Leśne przedszkola odpowiadają jakoby na zagrożenia współczesnego świata, w leśnym przedszkolu nie ma bowiem drzwi, dachu i ścian - nie ma budynku. Miejscem przebywania dzieci jest las, łąka, wydmy - w zależności od struktury krajobrazu w danym miejscu. Niezależnie od tego, czy świeci słońce, czy pada deszcz lub śnieg, dzieci z nauczycielami są zawsze (przez cały rok) na świeżym powietrzu.

W dzisiejszych czasach ludzie funkcjonują w ciągłym pośpiechu, stresie. Przechodząc przez park, mijając urokliwe ogrody, łąki, nie zauważają piękna natury. Przyroda w życiowym pościgu za konsumpcją doskonałą staje się coraz mniej znaczącym tłem życia lub co najwyżej źródłem tlenu (Dymara, Michałowski, Woltman-Mazurkiewicz, 1998: 15). Ponadto ludzie tracą życie duchowe, zatracają się w konsumpcji i produkcji. Gromadzą dobra materialne, a jednocześnie odczuwają pustkę istnienia. Aby temu zjawisku zapobiegać, należy:

- umożliwić dzieciom wszechstronne poznanie przyrody i rządzących nią praw, zrozumienie jej związków i zależności zachodzących w świecie przyrody;

- umożliwić najmłodszym wszechstronne poznanie otaczającego ich środowiska społecznego, zrozumienie związków i zależności zachodzących między ludźmi;

- umożliwić dzieciom poznanie samych siebie w toku zabawy, działania i pracy (Dymara, Michałowski, Woltman-Mazurkiewicz, 1998: 113-119).

Funkcjonowanie leśnych przedszkoli w pełni realizuje powyższe postulaty. Dają one szansę, by mimo realiów współczesnego świata dzieciństwo nadal było szczęśliwym okresem obfitującym w mnogość polisensorycznych doświadczeń oraz by był to czas, który stanie się solidnym fundamentem do budowania dobrego i satysfakcjonującego życia $\mathrm{w}$ dorosłości. Celem niniejszego artykułu jest scharakteryzowanie funkcjonowania leśnych przedszkoli w Niemczech w kontekście realiów dzieciństwa we współczesnym świecie. 


\section{Dzieciństwo we wspólczesnym świecie}

Przełomowym okresem dla kształtowania się współczesnego obrazu dzieciństwa było oświecenie. Zaczęto wtedy dostrzegać małego człowieka, jego charakterystyczne cechy i potrzeby. Przede wszystkim działo się to za sprawą dwóch ideologów dzieciństwa: Johna Locka (dziecko rodzi się jako czysta karta, a wychowanie ma tę pustkę wypełnić) i Jeana Jacques’a Rousseau (dziecko przychodzi na świat $\mathrm{z}$ wieloma nieskażonymi cnotami, a wychowanie ma przede wszystkim chronić je przed niszczącym wpływem świata). Kolejną postacią, która wywarła znaczący wpływ na obraz dzieciństwa, był Janusz Korczak. W jego pedagogice dziecko to obywatel i partner dorosłego. Korczak nadaje dziecku podmiotowość i mówi o dialogu między dorosłym a dzieckiem, który polega na wsłuchiwaniu się w dziecko. Budowało to nowe relacje międzyludzkie oparte na wzajemnym szacunku i prawie do odmienności. Natomiast współcześni badacze dzieciństwa stawiają tezę o likwidacji dzieciństwa. Przestają już istnieć przestrzenie charakterystyczne tylko dla dzieci. Media, komunikacja społeczna, społeczeństwo informacyjne i nowe technologie sprawiają, że dzieci mogą się znaleźć wszędzie i mogą zdobyć wszystkie potrzebne im informacje. Obecnie kultura dziecięca nie jest już domeną dzieci, kurczy się jej przestrzeń i specyfika. Dziecko przy komputerze, przy zabawce, w przestrzeni wirtualnej przestało być dziecięcym kreatorem, a stało się przede wszystkim konsumentem obrazów i towarów. Dziecko konsumuje tak jak dorosły, tylko trochę mniej i inaczej (Pilch, 2003: 868-871).

Sposób wychowywania dzieci odgrywa centralną rolę w każdym społeczeństwie. W końcu to dzieci są naszą przyszłością, więc stworzenie im odpowiednich warunków i możliwości do pełnego rozwoju jest powiązane z pomyślnością wszystkich obywateli danej społeczności. We współczesnym świecie rodzice coraz częściej zadają sobie pytanie, jak wychować swoje dziecko na szczęśliwego dorosłego, który spełni się w interesującej pracy, dużo zarobi i będzie miał ładne mieszkanie. Szczególnie we wrześniu można zaobserwować tysiące rodzicielskich aut wyjeżdżających na ulice, by dowieźć swoje dzieci na zajęcia dodatkowe. Dzieci stają się centrum świata dla swoich rodziców, co oczywiście jest pozytywnym zjawiskiem, ale niesie ze sobą także spore ryzyko - w morzu pytań (Szkoła prywatna czy publiczna? Angielski czy chiński? W jaką wiedzę wyposażyć dziecko na przyszłość?) łatwo dziś zgubić same dzieci. Dr Julita Wojciechowska (Instytut Psychologii UAM w Poznaniu) wskazuje, że szczególnie widoczne w polskiej klasie średniej przeładowanie najmłodszych zajęciami na konto ich sukcesu w późniejszym życiu służy również poczuciu bezpieczeństwa rodziców. Dorośli przenoszą ambicje na swoje potomstwo, czyli dzieci końcowego Peerelu programują dzieci XXI wieku i ich spektakularne kariery. Strasznie się boją, że mogliby 
nie zauważyć jakiegoś talentu u swojego jedynaka. Im więcej zajęć ma dziecko, tym dalej od wyrzutów sumienia jest dorosły. Mimo to rodzice z klasy średniej (nazywanej również nową burżuazją) są w pewnym stopniu zdezorientowani, gdyż nie można ukształtować szczęśliwego człowieka przyszłości (w tak dynamicznie zmieniającej się rzeczywistości) za pomocą współcześnie dostępnych narzędzi. Zauważa się także, że nowi mieszczanie coraz częściej zamykają się w luksusowych gettach i tworzą hermetyczne grupy. Ich dzieci odziedziczą gotowe miejsca społeczne, zawodowe i nie będą wiedziały nic o życiu poza granicami swojego getta. Niestety, należą już do przeszłości przyjaźnie zawierane przez dzieci bawiące się pod blokiem, gdzie syn profesora $z$ synem dozorcy wzajemnie się od siebie uczyli. Ponadto zdecydowana większość rodziców podpowiada dzieciom, jakie zawody mają wybrać. Programowanie dzieci do tych zawodów rozpoczyna się często już u niemowlaków. Taka tendencja jest widoczna na całym cywilizowanym świecie, również w Polsce jest ona bardzo wyraźna (Kołodziejczyk, 2014: 10-12).

Współczesne dzieciństwo w literaturze przedmiotu nazywa się także toksycznym, a zjawisko to opisane jest chociażby w książce Toksyczne dzieciństwo Sue Palmer.

W naszej globalnej kulturze, w której obywatele są zdrowsi, zamożniejsi i bardziej uprzywilejowani niż kiedykolwiek w historii, dzieci z roku na rok stają się bardziej nieszczęśliwe. Od markotnych i niezadowolonych po depresyjne i dysfunkcyjne. Rośnie nam pokolenie, które nie kocha niczego poza swoimi problemami z nastawieniem do świata. (Palmer, 2008: 8)

We współczesnym świecie, szczególnie w państwach najlepiej rozwiniętych gospodarczo, jak Stany Zjednoczone, Japonia, Niemcy, Wielka Brytania, zaobserwowano w ciągu ostatnich trzydziestu lat wzrost liczby młodych ludzi mających problemy behawioralne, natomiast liczba młodzieży odznaczającej się zaburzeniami natury emocjonalnej wzrosła o 70\%. Przyczyny zaistniałej sytuacji są złożone i ściśle związane z nieprawdopodobnym tempem naszego cywilizacyjnego rozwoju. W ostatnich latach postęp przyspieszył tak bardzo, że ludzie nie potrafią już za nim nadążyć, a więc kultura ewoluuje szybciej niż nasza biologia. Występuje więc kolizja pomiędzy kulturą napędzaną techniką a biologicznym dziedzictwem człowieka, co niszczy w dzieciach zdolność myślenia, uczenia się i zachowania. Pamiętać należy, że dzieci muszą się dopiero wyuczyć nawyków cywilizowanego zachowania, skupiania uwagi, zasady w czasie odsuniętej nagrody, samokontroli, empatii i niemożliwe jest przyswojenie tego wszystkiego z prędkością światła. Rozwój człowieka nadal przebiega w powolnym tempie i dzieci we współczesnym świecie nadal potrzebują czasochłonnego wychowania, jakiego potrzebowali nasi przodkowie (Palmer, 2008: 8-22). 
Długie godziny spędzone przed ekranem telewizora, czy komputera niosą za sobą dalekosiężne skutki. Nadmierne oglądanie telewizji zabija wyobraźnię. Widzowie mają "na tacy” podany gotowy obraz, prosty, niezmuszający do żadnego wysiłku intelektualnego. Niegdyś dzieci słuchały opowiadanych im baśni, same wyobrażały sobie to, co słyszą, potem rozmawiały o swoich przeżyciach, wyobrażeniach. Ponadto zbyt długie siedzenie przed ekranem powoduje zaburzenia rozwoju mowy. Dzieci są biernymi odbiorcami przekazu słownego i nie biorą aktywnie udziału w komunikacji. Kolejnym bardzo ważnym skutkiem spędzania czasu oglądając programy telewizyjne są wady postawy. Brak ruchu, aktywności na świeżym powietrzu upośledza prawidłowy rozwój fizyczny (Haefner, 2002: 20-25). Panuje przy tym wyobcowanie, oddalenie od natury, co skutkuje niewykształceniem świadomości ekologicznej. Także wspieranie rozwoju inteligencji emocjonalnej jest zaniedbane, co może prowadzić do wzrostu przemocy i zachowań aspołecznych.

Równie zdumiewające są przemiany społeczne. Coraz rzadziej spotyka się rodziny wielopokoleniowe, coraz więcej matek pracuje, miejsca pracy zmieniają się bardzo szybko, co sprawia, że życiu zawodowemu rodziców towarzyszy coraz większy stres, małżeństwa są mniej stabilne, coraz popularniejsze stają się rodziny patchworkowe (Palmer, 2008: 21). Ponadto coraz mniej dzieci przychodzi na świat, a rodzice coraz częściej decydują się na posiadanie tylko jednego dziecka (skutkiem tego jest brak towarzysza zabawy dla jedynaka).

Współcześnie obserwuje się także rozluźnienie powiązań pomiędzy trzema najważniejszymi środowiskami życia dzieci: domem, sąsiedztwem i społecznością miejską. Dzieci żyją w tych środowiskach jak w niezależnych od siebie enklawach, których powiązania przestrzenne, funkcjonalne, społeczne i symboliczne nie są im znane, gdyż nie przemieszczają się same między nimi i nie uczą się ich rozumieć. Przebywanie w szkole, wśród kolegów z podwórka, w domu odznacza się separacją czasową (np. dzieci zawożone do „lepszych” szkół, ich dzień dzieli się na czas szkoły, zajęć pozalekcyjnych, czas w domu) i przestrzenną (aktywność dzieci przebiega w zamkniętych pomieszczeniach - szkoły, centrów handlowych, obiektów rekreacyjnych). Ponadto strach dorosłych przed przestrzenią miejską projektowany na dzieci implikuje wykluczenie najmłodszych z publicznych przestrzeni miejskich (ulice, place, parki). Tymczasem niekontrolowana przez dorosłych obecność dziecka w publicznych przestrzeniach miejskich na jego własnych zasadach jest istotnym warunkiem rozwoju jego twórczych i poznawczych zdolności. Zjawisko wykluczenia dzieci z przestrzeni miejskiej następowało równolegle do procesu XX-wiecznej „nowoczesnej urbanizacji”. Nowoczesne miasta (zwłaszcza amerykańskie) w XX wieku postrzegano jako miejsce zagrożenia, $\mathrm{w}$ którym $\mathrm{z}$ łatwością dziecko mogło stać się ofiarą. Jed- 
nakże miasta z przełomu XIX i XX wieku stanowiły przestrzeń, w których dzieci mogły samodzielnie przebywać i wyraźnie zaznaczały $\mathrm{w}$ tej przestrzeni swoją obecność. Ulica była najważniejszą przestrzenią dziecięcych zabaw, ponieważ małe mieszkania zajmowało często kilka rodzin i nie było warunków do zabaw w pomieszczeniach zamkniętych. Warto podkreślić, że świat dziecięcych zabaw był tym bogatszy i bardziej twórczy, im mniej gotowych zabawek i placów zabaw oferowali dziecku dorośli. Również powojenne przemiany przestrzeni miejskiej (rozwój komunikacji samochodowej i przestrzenna restrukturyzacja miasta) powodowały stopniowe wykluczanie $\mathrm{z}$ niej dzieci. Także późniejsze zmiany przyczyniły się do wykluczenia dziecka z przestrzeni miejskiej, a były one związane z metropolizacją - splot czynników ekonomicznych, technologicznych, przestrzennych, społecznych wywierających wpływ na charakter przestrzeni miejskich, wynikających ze zmiany funkcji i pozycji miast obecnie w życiu społecznym i kulturze (Skórzyńska, 2011: 32-34). Obecne więc warunki życia ograniczają możliwość swobodnego poruszania się. Dzieci (coraz częściej jedynacy) bawią się w swoich małych, często „zagraconych” zabawkami pokojach same lub z jedną koleżanką/kolegą. Duże grupy dzieci bawiących się niegdyś na ulicy lub, wspólnym osiedlu są już rzadkością. Skutkiem tego jest brak doświadczenia socjalnych kontaktów i nieumiejętność zachowania się w dużej grupie. Poza tym, przebywanie w zamkniętych pomieszczeniach, przemieszczanie się wszędzie samochodem, sprawiają, że aktywność fizyczna i wygimnastykowanie wśród dzieci są na bardzo niskim poziomie. Tymczasem zadbanie o prawidłowy rozwój fizyczny implikuje dalszy prawidłowy i przebiegający bez zakłóceń rozwój najmłodszych.

Dorośli powinni dziś sensownie towarzyszyć dziecku w rozwoju, pomagać mu poznać siebie, swoje możliwości, a także uczyć akceptacji samego siebie. By dziecko mogło samo siebie poznać, potrzebuje czasu oraz miejsca na eksperymenty. Wszystko to wymaga odejścia od stereotypów dotyczących edukacyjnego wyścigu i rywalizacji, zejścia z wytyczonych, powszechnie uczęszczanych ścieżek, a podarowania dziecku czegoś więcej - autentycznej uwagi i czasu. W głośnym filmie dokumentalnym „Alfabet” reżyserii Erwina Wagenhofera (premiera 11 października 2013) przedstawiono wiele czynników wpływających negatywnie na współczesny system szkolnictwa i na ogólny rozwój dzieci. Edukacja opierająca się na rywalizacji (kiedy to współpraca i umiejętność działania w grupie są szansą na innowacyjne i skuteczne rozwiązywanie problemów), kontrolowaniu i testowaniu nie pozwala na indywidualny rozwój, a prowadzi do wyprodukowania mas posłusznych konsumentów, którzy tak naprawdę są nieszczęśliwi, bo uniemożliwiono im odkrycie swoich talentów i zainteresowań.

Nie sposób wyliczyć wszystkich czynników negatywnie wpływających na dzieciństwo we współczesnym świecie. Ważne jest, że zaczęto zauważać nega- 
tywne konsekwencje tak dynamicznego obecnie rozwoju cywilizacji. Wszystkie te przedstawione powyżej przemiany (które z biegiem czasu prowadzą do zakłócenia możliwości doświadczalnych u dzieci i ich prawidłowego rozwoju psychofizycznego) stały się decydujące dla zakładania leśnych przedszkoli. Waldkindergaerten zaczęły powstawać i stały się wspaniałą alternatywą do tradycyjnej edukacji przedszkolnej, by dać szansę dzieciom na dzieciństwo, w którym jest czas na swobodną zabawę, polisensoryczne doświadczenia, bliski kontakt z przyrodą, bezpośrednie przeżywanie rytmu pór roku, poznanie siebie i swoich zainteresowań. Leśne placówki oferują swoim podopiecznym znacznie więcej korzyści, które dokładniej zostaną przedstawione poniżej.

\section{Leśne przedszkola w Niemczech}

„Leśna pedagogika” ma swoje korzenie w Szwecji, w której od 1892 roku znajduje się organizacja Friluftsfraemjandet, oferująca całoroczną aktywność na łonie natury dla dzieci w różnym wieku. W połowie XX wieku powstała pierwsza grupa leśnych przedszkolaków. W blisko położonej Danii pedagogiczne nowości płynące ze Szwecji nie pozostały bez odpowiedzi: Ella Flatau z Soelleroed wyrusza w połowie lat pięćdziesiątych ze swoimi dziećmi do lasu. Nieco później zaczyna także zabierać ze sobą na codzienne wycieczki dzieci swoich sąsiadów. W ten sposób zaczęła rozwijać się rodzicielska inicjatywa, która wkrótce założyła pierwsze leśne przedszkole. Obecnie funkcjonuje w Danii około 100 organizacji tego typu (Miklitz, 2007: 14).

W Niemczech pierwsze leśne przedszkole (nazwa ta występuje zamiennie z przyrodniczymi i wędrownymi przedszkolami) zostało założone w Wiesbaden przez Ursulę Sube. Śmierć jej męża zmusiła ją do samotnego wychowywania ich pięcioletniego syna. Ponieważ w tamtych czasach brakowało miejsc w przedszkolach i nie mogła znaleźć odpowiedniej placówki dla swojego dziecka, postanowiła założyć leśne przedszkole, które wiosną 1968 roku otrzymało urzędową zgodę na działalność. Ursula Sube nie posiadała wykształcenia pedagogicznego, dlatego też jej przedszkole nie otrzymywało dotacji od państwa, a było wyłącznie finansowane przez składki rodziców. Co ciekawe, pani Sube nie zdawała sobie sprawy $\mathrm{z}$ istnienia leśnych przedszkoli w Danii. Z wypracowanego modelu Sube nie rozwinęły się żadne dalsze inicjatywy (Haefner, 2002: 34).

W kwietniu 1991 roku początkujące nauczycielki przedszkolne Kerstin Jebsen i Petra Jaeger przeczytały w czasopiśmie pedagogicznym „Spielen und Lernen” artykuł Ursuli Friedrich pt. „Przedszkole bez drzwi i ścian” („Ein Kindergarten ohne Tueren und Waende”), opisujący funkcjonowanie duńskich leśnych 
przedszkoli (Haefner, 2002: 33). Przedstawiona koncepcja odpowiadała ich własnemu wyobrażeniu o pracy z dziećmi, dlatego udały się na hospitacje przedszkoli w Danii i rozwijając interesującą je koncepcję, założyły stowarzyszenie zrzeszające zwolenników „leśnej pedagogiki”. Dzięki ich zapałowi stopniowo udało im się przekonać władze do pomysłu otworzenia leśnego przedszkola. I tak w 1993 roku zostało otwarte pierwsze państwowe leśne przedszkole w Flensburg. Inicjatorki dokonały ciężkiej pionierskiej pracy i włożyły wiele wysiłku w uzyskanie przychylności urzędników, którzy w tym czasie byli bardzo sceptycznie nastawieni do takiej alternatywnej formy pracy z dziećmi. Dzięki intensywnemu informowaniu opinii publicznej o tym dokonaniu, oraz licznym odwiedzającym to przedszkole - idea leśnych przedszkoli rozprzestrzenia się na całe Niemcy.

Już w 1994 roku założono kolejne leśne przedszkole w Berglen (Badenia-Wirtembergia) i w Luebeck. W połowie lat 90 . zostały otwarte następne takie placówki, czemu towarzyszyła dyskusja pełna kontrowersji na łamach prasy pedagogicznej. Dzisiaj w całych Niemczech działa około 450 organizacji tego typu. W 1996 roku powołane zostało „Bundesarbeitskreis der Naturkindergaerten in Deutschland” (Związkowe Koło Pracy Przyrodniczych Przedszkoli w Niemczech), a w roku 2000 - Federalne Zrzeszenie. Landowe Stowarzyszenia działają w Bawarii, Badenii-Wirtembergii, Nadrenii-Westfalii, Szlezwiku-Holsztynie i Hesji.

Waldkindergarten w swojej pierwotnej formie różni się istotnie od tradycyjnego przedszkola. Nie ma ono bowiem budynku. Dzieci bawią się i spędzają czas niezależnie od pogody zawsze na świeżym powietrzu. Umożliwia to bezpośrednie poznanie całorocznego rytmu przyrody. W lesie dzieci mają do dyspozycji znacznie więcej przestrzeni do ruchu i aktywności niż w zamkniętych pomieszczeniach, zatem mogą zaspokoić swoją naturalną potrzebę aktywnej zabawy. W leśnym przedszkolu nie tylko motoryka duża może się lepiej rozwijać niż w tradycyjnych placówkach, również kształcenie precyzyjnych i starannych ruchów nie jest zaniedbywane (Haefner, 2002: 34).

Otaczająca natura wpływa na dobre samopoczucie dzieci. System odpornościowy zostaje wzmocniony przez długie przebywanie na świeżym powietrzu. Przedszkolaki z takich placówek chorują rzadziej niż dzieci z tradycyjnych przedszkoli, gdzie w pomieszczeniach często panuje zbyt wysoka temperatura (Gamillscheg, 1987: 14). W lesie, dzięki wolnej przestrzeni, dzieci mogą lepiej redukować nagromadzoną agresję, co jest bardzo korzystne nie tylko dla tych nadpobudliwych. Poza tym rozwija się u nich pozytywny stosunek do przyrody. Najmłodsi odbierają las jako coś niepowtarzalnego, co należy szanować i chronić. Tak zostają położone podwaliny do świadomej odpowiedzialności za naturę w późniejszych latach ich życia. 
Istnieje diametralna różnica między podejściem do zabawek w leśnym a tradycyjnym przedszkolu. W leśnych placówkach całkowicie rezygnuje się z gotowych zabawek na rzecz narzędzi i półproduktów, z których dzieci same tworzą dla siebie zabawki. Wspiera to w dużej mierze rozwój mowy, ponieważ dzieci są skazane na werbalną komunikację ze współtowarzyszami zabawy. W lesie nie ma nadmiernie pobudzających zabawek, co często ma miejsce w normalnych przedszkolach. Przedszkolaki bawią się korzeniami, gałęziami, zamiast lalkami czy klockami lego. Takie zachowanie rozwija samodzielność, kreatywność i przede wszystkim fantazję dzieci.

Wielkość grup w leśnych przedszkolach jest mniejsza niż w innych przedszkolach. Najczęściej formują się one z 15 do 20 dzieci w wieku od 3 do 6 lat. Na każdą grupę przypada co najmniej dwóch opiekunów, a w niektórych leśnych przedszkolach nawet trzech. Dzięki temu każde dziecko może liczyć na czas i uwagę nauczyciela. W wypadku, gdy jeden z pracowników jest nieobecny, najczęściej na zastępstwo przychodzi chętna mama. Współpraca rodziców z leśnymi placówkami jest niezwykle prężna i dynamiczna.

Koszty utrzymania Waldkindergarten są mniejsze niż w przypadku tradycyjnych placówek. Nie ma wydatków na budynek, ogrzewanie, czyszczenie/sprzątanie, utrzymanie obiektu w dobrym stanie, konserwacje itd. Ponadto nie trzeba wydawać pieniędzy na zabawki, nowe ozdoby do sali, dywany itd. W leśnych przedszkolach wydaje się jedynie pieniądze na materiały do majsterkowania, zajęć plastycznych i technicznych, narzędzia i inne drobne, niezbędne zakupy.

Doświadczenia dzieci z okresu przedszkolnego mają szczególne znaczenie w ich całym późniejszym życiu. Waldkindergaerten oferują wszechstronne możliwości i wystarczająco dużo przestrzeni do nabywania bezpośrednich doświadczeń. W dzisiejszych czasach wiele dzieci nie ma kontaktu z przyrodą, a przecież przebywanie w otoczeniu natury przyczynia się do ich optymalnego rozwoju, (Haefner, 2002: 35-37).

Niemieckie Waldkindergaerten, idąc za przykładem duńskich leśnych przedszkoli, stwarzają różne modele funkcjonowania. Dwoma podstawowymi formami występowania leśnych przedszkoli w Niemczech są: „der reine Waldkindergarten” - klasyczne, typowe leśne przedszkole i „der integrierte Waldkindergarten” - zintegrowane leśne przedszkole.

W typowych leśnych przedszkolach dzieci spędzają całe przedpołudnie w lesie, na określonym, przestrzennie ograniczonym obszarze. Las jest tutaj głównym miejscem pobytu dzieci. Często jednak miejsca pobytu leśnych przedszkoli odzwierciedlają w całości krajobrazową różnorodność Niemiec. Tak np. możemy spotkać przyrodnicze przedszkole na wyspie czy w Angielskim Ogrodzie w Mo- 
nachium. Las jest łatwo osiągalny i z reguły publicznie dostępny, dlatego większość organizacji tego typu w Niemczech oznacza się jako leśne przedszkola.

Czas opieki wynosi zazwyczaj od czterech do sześciu godzin dziennie (z reguły latem są to minimum cztery godziny, a zimą minimum trzy godziny), pięć dni $\mathrm{w}$ tygodniu. $\mathrm{W}$ zlokalizowanych wyżej geograficznie przedszkolach czas otwarcia ulega skróceniu podczas zimy, natomiast w okresie letnich miesięcy jest odpowiednio wydłużony, aby wypracować założoną liczbę godzin. Niektóre przedszkola oferują dodatkowo w tygodniu jedno lub dwa popołudnia opieki dla przedszkolaków. Liczba leśnych przedszkoli z wydłużonym czasem otwarcia ciągle wzrasta (Miklitz, 2007: 16).

Jak wcześniej zostało wspomniane, takie przedszkola nie dysponują stałym budynkiem. Bawaria wyłamała się z tego schematu i tam leśne przedszkola zgodnie z przepisami muszą posiadać pomieszczenia ochronne (ten wymóg obecnie na nowo podlega dyskusji). Jednakże każde przedszkole ma tzw. „schron”. Często w tym celu używa się kontenerów biurowych używanych na placach budów, które w odpowiedni sposób są zaadaptowane. Przy ekstremalnych warunkach atmosferycznych, jak np. burza, nawałnica, sztorm czy grad, dzieci chronią się w takim kontenerze. Na co dzień „schron” pełni funkcję magazynu: przechowuje się w nim materiały do majsterkowania, rezerwową odzież dzieci itp.

Poniżej temperatury $-6^{\circ} \mathrm{C}$ oferuje się alternatywne zajęcia w ogrzewanych budynkach, aby dzieci mogły nieprzerwanie, bez względu na warunki atmosferyczne, uczęszczać do przedszkola. Najczęściej w takich sytuacjach korzysta się z gminnych pomieszczeń, np. świetlic, pokoi przeznaczonych na spotkania obywateli danej miejscowości czy sal należących do stowarzyszeń lub związków działających na terenie gminy. Takie pomieszczenia $\mathrm{w}$ godzinach przedpołudniowych zazwyczaj są nieużywane i spokojnie można je zagospodarować $\mathrm{w}$ ten sposób (Miklitz, 2007: 17).

„Der integrierte Waldkindergarten” (zintegrowane leśne przedszkole): W Danii model zintegrowanych leśnych przedszkoli jest bardzo rozpowszechniony, natomiast $\mathrm{w}$ Niemczech są one jeszcze wyjątkami. $\mathrm{W}$ zintegrowanych leśnych przedszkolach pedagogiczna koncepcja leśnych placówek zostaje włączona w działalność przedszkoli tradycyjnych. Obecnie w Niemczech istnieją różne, zintegrowane formy leśnych przedszkoli:

- tradycyjne przedszkola $\mathrm{z}$ leśnymi grupami;

- leśne przedszkola współpracujące z tradycyjnymi przedszkolami.

Leśna grupa $\mathrm{w}$ przedszkolach tradycyjnych może występować jako otwarty zespół, do którego przyporządkowuje się dzieci z różnych grup, według ich własnego upodobania. Taka grupa każdego dnia wychodzi poza teren przedszkola i spędza przedpołudnia w lesie. Ale mogą być też stałe, zamknięte leśne grupy, 
z cotygodniową bądź comiesięczną odgórnie zaplanowaną zmianą dzieci, tak aby każdy przedszkolak miał szansę należeć do leśnej grupy.

Kooperacja między leśnymi, a tradycyjnymi przedszkolami wygląda w ten sposób, że leśne przedszkolaki spędzają przedpołudnia w lesie, a popołudnia w murach przedszkola. Dzięki takiej współpracy leśne przedszkola otrzymują kwaterę od przedszkoli typowych, na czas godzin wczesnoporannych, czy popołudniowych. Przykładowo: już od 7.30 do ok. 9.00 mogą dzieci spędzać czas w przedszkolu. Potem wyruszają do lasu. Następnie w godzinach popołudniowych jest zagwarantowana dalsza opieka w murach przedszkolnych (Miklitz, 2007: 18).

Kolejnymi formami funkcjonowania leśnych przedszkoli w Niemczech są tygodniowe projekty i regularne leśne dni. Istotą tygodniowych projektów jest bezpośrednie doświadczanie natury w przedszkolach tradycyjnych. Najczęściej przedsięwzięcie takie trwa od jednego do trzech tygodni. Jeśli jest możliwość, to uprzednio nauczyciel danego przedszkola hospituje pracę w klasycznym leśnym przedszkolu, ażeby zebrane przez niego doświadczenia mogły wpłynąć na plan projektu tygodniowego. Ważne jest tutaj także poinformowanie odpowiednio wcześniej rodziców, oraz ich współudział w projekcie.

Coraz częściej tradycyjne przedszkola oferują swoim podopiecznym leśny dzień regularnie w każdym tygodniu (np. każdy piątek staje się leśnym dniem). Przez intensywne informowanie opinii publicznej oraz wiele hospitacji nauczycieli w Waldkindergaerten, idea „leśnej pedagogiki” coraz częściej zostaje przenoszona do tradycyjnych przedszkoli (Miklitz, 2007: 19).

Należy podkreślić, że natura pobudza nasze zmysły w różnorodny sposób. Każdy kij, drzewo ma inną powierzchnię. Zbutwiałe drewno pachnie inaczej niż świeżo ścięte. Mech jest miękki w dotyku. Bardzo dobrze słychać kroki w liściach. Ściółka leśna paruje po letnim deszczu. Te i wiele innych wrażeń zapadną dziecku głęboko w pamięć na całe życie. W leśnych przedszkolach dzieci mają możliwość wejścia w bliską zażyłość z roślinami i zwierzętami. Dzieci, ucząc się, chcą widzieć, dotykać i doświadczać, mają emocjonalny stosunek do przedmiotu ich zainteresowania. Informacje zdobywane (a nie przekazywane przez dorosłych) w taki sposób z łatwością zostaną przyswojone przez dzieci. W tych placówkach nie zapomina się, że dzieci odznaczają się naturalną, dociekliwą i badawczą postawą.

W leśnych przedszkolach podkreśla się również, iż rozwój fizyczny i intelektualny są ze sobą ściśle powiązane. Dzieci, których swobodne poruszanie się jest ograniczone, nie doceniają swoich możliwości. Przedszkolaki, które wdrapują się na drzewa, uczą się zarazem, jak z nich spadać, aby się nie skaleczyć. Takie dzieci wygrywają pewność siebie i samoświadomość, co wpływa na ich nastawienie do 
życia. Doświadczanie swoich fizycznych granic buduje stabilny fundament, dzięki któremu radzimy sobie lepiej z psychicznym obciążeniem i sytuacjami trudnymi (Miklitz, 2007: 28).

\section{Zakończenie}

Reasumując, należy zaznaczyć, iż nieprawdopodobne tempo cywilizacyjnego rozwoju powoduje, że coraz więcej dzieci, mimo wszelakich dóbr materialnych, jest nieszczęśliwych. Nieszczęśliwe dzieciństwo implikuje niestety zazwyczaj nieszczęśliwą dorosłość. Tak trudna sytuacja dzieciństwa we współczesnym świecie wymaga, by dorośli szukali rozwiązań, dzięki którym dzieci będą mogły cieszyć się każdym dniem, który przyniesie bogate doświadczenia i możliwość swobodnej zabawy. Leśne przedszkola są jedną z możliwości rozwiązania problemów, z którymi borykają się współczesne dzieci. U leśnych przedszkolaków wspiera się motorykę poprzez naturalne aktywności wynikające $\mathrm{z}$ najbliższego otoczenia, dzieci bezpośrednio przeżywają rytm pór roku i poznają towarzyszące im zjawiska przyrodnicze, postrzegają świat za pomocą wszystkich zmysłów, uczą się ciszy i poszanowania przyrody, całościowo zdobywają wiedzę. W leśnych przedszkolach dzieci mają czas, by w swobodnej zabawie nawiązywać głębokie kontakty z rówieśnikami, dzięki temu rozwija się (tak często współcześnie zaniedbywana) inteligencja społeczna i emocjonalna. Nie sposób wymienić wszystkich pozytywnych aspektów uczęszczania najmłodszych do leśnych placówek. Zrozumienie istotności bliskiego kontaktu dzieci z przyrodą i wybór opierającego się na tym założeniu leśnego przedszkola, będzie szansą na prawidłowy rozwój psychofizyczny dzieci. Dzięki Waldkindergaerten dzieciństwo we współczesnym świecie staje się znowu szczęśliwym czasem, w którym dzieci zdobywają wiele nowych doświadczeń, nawiązują głębokie kontakty z rówieśnikami, mają czas na zabawę, sensownie przygotowują się do zmierzenia się z późniejszymi życiowymi wyzwaniami.

\section{Literatura}

Daszewska W. (1948). Przyroda w przedszkolu. Warszawa.

Dymara B., Michałowski S.C., Woltman-Mazurkiewicz L. (1998). Dziecko w świecie przyrody. Kraków.

Gamillscheg J. (1987). Feiern unter Gottes freiem Himmel. „Stuttgarter Zeitung“ v. 21.

Haefner P. (2002). Natur- und Waldkindergaerten in Deutschland - eine Alternative zum Regelkindergarten in der vorschulischen Erziehung. Buergstadt. 
Kołodziejczyk M. (2014). Dziecko: poradnik dla programistów. „Polityka” nr 35.

Miklitz I. (2007). Der Waldkindergarten. Dimensionen eines paedagogischen Ansatzes. Berlin-Duesseldorf-Mannheim.

Mikołuszko W. (2012). Łapać na robaka. „Polityka” nr 35.

Palmer S. (2008). Toksyczne dzieciństwo. Wrocław.

Pilch T. (red.) (2003). Encyklopedia pedagogiczna XXI wieku. T. I (A-F). Warszawa.

Skórzyńska A. (2011). Sztuczki. Twórcza aktywność dziecka w marginalizowanych obszarach miejskich. „Studia Kulturoznawcze” nr 1.

\section{Forest Kindergarten - Wald kinderga erten - in Germany and the Modern Concepts of Childhood}

\section{Summary}

Forest Kindergarten is the response to challenges and problems of present childhood especially dynamic development of civilization. Long-term social transformations caused disturbances in psychophysical development of children. Der Waldkindergaerten (German name for Forest Kindergarten) in Germany are the new alternative and perspective in kindergarten pedagogy. They give children a chance to have close contact with the nature. Forest kindergarten has no doors, roof and walls - no building. Children are spending time in forest, meadow or dunes - depending on local ecosystem. No matter if it's sunny, rain or snow children and their teachers are always in the fresh air. Kids in natural environment are confronted with structures that make a strong impression on them and which they can't experience in human-created world. A distinctive feature of forest kindergarten and its main goal is holistic education which is inseparably connected to the concept of this alternative educational institutions. This article characterizes forest kindergarten in Germany in the context of modern concepts of childhood.

It is worth emphasizing that the nature stimulate our senses in many different ways. Every stick or tree has different surface. Moldy wood smells different than freshly cut. Moss is soft to the touch. It is easy to hear human footsteps walking through rustling leaves. Forest litter evaporate after summer rain. Children remember these and many other impressions forever. Kids in forest kindergarten have a chance to get familiar with various plants and animals. While learning, children want to see, touch and gain experience because they have an emotional attitude to their object of interest. Knowledge gathered in this way is adopted very easily. Teachers in forest kindergarten don't forget that kids are inquisitive by instinct.

Modern childhood in the literature for pedagogy is often called "toxic childhood". In the modern world especially in well developed countries such as United States, Japan, Germany or Great Britain the number of young people with behavioral problems increased dramatically during last thirty years. The number of youth with emotional problems increased by $70 \%$. The reasons of this situation are complex and strictly related to incredible pace of civilization development. Currently the progress accelerated so much that people can't follow it anymore. Our culture evolves faster than our biology. There is a conflict of interest between culture which is driven by technology and human biological heritage. This conflict disturb children ability of thinking, learning and 
behaving. It should be remembered that kids have to learn certain behaviors like self-control, empathy, concentration, patience. It isn't possible to learn it in the speed of light. Children development still needs a lot of time. Modern kids need time-consuming education like their ancestors. Fast pace of life cause children to be unhappy, even if their financial status is high. Unfortunately unhappy childhood very often implies unhappy adulthood. Adults have to find a solution for uneasy modern childhood.

Children throughout the developed world are suffering, with obesity, dyslexia, ADHD, and other serious ailments on the rise. And it's not simply that our diagnostic ability has improved there are very real and growing problems. The main reasons are poor diet, lack of exercise, family problems, early failure at school, lack of motivation and sleep deprivation, modern lifestyle of TV, computer games, and cell phones. This combination of factors, along with parents' increasingly stressful lives, means that we are developing a toxic new generation, with its health and brains at risk. 21 st century life is damaging our children. In the last couple of decades, huge changes in adult lifestyles have affected the way we look after children, both at home and in school. Electronic technologies are great for us but are not good for our children. Because of them, the world is changing too fast. People are finding it harder and harder to keep up, and are becoming confused about their priorities. Parents, instead of spending time reading to their children at night or talking to them, plonk them in front of the television and treat it as an electronic babysitter. They buy their children electronic games and junk food to keep them quiet, and spend less and less time with them. Thus they deprive them of what they need most - a good old-fashioned upbringing where parents are in charge, providing a safe, calm and nurturing environment, where they can develop at their own pace and learn important moral and cultural values that are the foundation of a stable society. For more than a decade, researchers have understood that frequent or continual stress on young children who lack adequate protection and support from adults, is strongly associated with increases in the risks of lifelong health and social problems. What is more, children that spend most of their time indoor have no contact with nature and their physical development is neglected.

Forest kindergarten is the solution for above mentioned problems. Kids are spending their time in calm and wild environment. They can see and feel the rhythm of the seasons and experience the natural phenomenons. Kids become friendly with nature. Forest kindergarten ensure children free play time, which is necessary to make deep contacts with classmates. Thanks to that they develop their emotional and social intelligence. It is hard to mention all positive aspects of forest kindergarten. It is a place where kids, despite the dangers of modern world, may have happy and peaceful childhood. 